\title{
MEMBANGKITKAN MOTIVASI DAN JIWA KEIRAUSAHAAN DI PONDOK PESANTREN YATIM ALHANIF KELURAHAN SERUA KECAMATAN CIPUTAT KOTA TANGERANG SELATAN
}

\author{
Enny Savitri, Sheila Ardilla Yughi, Ambar Widya Lestari, \\ Taufik Awaludin, Eko Cahyadi \\ Universitas Pamulang \\ dosen01700@unpam.ac.id
}

\begin{abstract}
Entrepreneurship has an important role to play in making society more creative and independent. To become an entrepreneur, you need to have concepts and strategies in dealing with difficult situations when facing challenges in front of your eyes. Currently the number of entrepreneurs in Indonesia is only 570,339 people or $0.24 \%$ of the population of 237.64 million people. Whereas to be a developed nation, it takes at least $2 \%$ of the entrepreneurial population. Productive entrepreneurial programs, become one of the top work priorities. Based on this phenomenon, it is necessary to prepare the young generation who have a high entrepreneurial spirit. And this young generation, is no exception with the students at the Islamic Boarding Schools. They need to be given motivation and a way of reading possible business opportunities to be taken. Given the importance of sharing knowledge and experience from entrepreneurs to students, it is necessary to hold Community Service related to motivation and entrepreneurial spirit for students. This activity was carried out at Alhanif Islamic Boarding Schools. Some of the methods used in this training are, lectures, group discussions and sharing experiences. Lecture method is a method used, where the presenter in the training provides material explanation directly to all participants. The discussion method was carried out when the presenter submitted the case to the participants, then the participants were asked to discuss with their group to find a solution to the problem of the proposed case. The result of this devotional activity is that students can be more educated on how to generate motivation and entrepreneurial spirit and how to read the business opportunities that can be taken by them. So that the students can participate in the activities of Small and Medium Enterprises in Indonesia. Thus, it is expected that the activities of Small and Medium Enterprises in Indonesia can progress and develop.
\end{abstract}

Keywords: Motivation, Entrepreneurial Spirit, Islamic Boarding Schools 


\begin{abstract}
Abstrak
Kewirausahaan memiliki peranan penting untuk menjadikan masyarakat lebih kreatif dan mandiri. Untuk menjadi wirausaha perlu mempunyai konsep dan strategi dalam menghadapi situasi yang sulit ketika menghadapi tantangan di depan mata. Saat ini jumlah wirausaha di Indonesia hanya 570.339 orang atau $0,24 \%$ dari jumlah penduduk yang sebanyak 237,64 juta orang. Padahal untuk jadi bangsa maju, dibutuhkan wirausaha minimal 2\% dari jumlah penduduk. Program wirausaha produktif, menjadi salah satu prioritas kerja utama. Berdasarkan fenomena tersebut, maka sedini mungkin perlu dipersiapkan generasi muda yang memiliki jiwa kewirausahaan yang tinggi. Dan generasi muda ini, tidak terkecuali dengan para santri yang ada di Pondok Pesantren. Mereka perlu diberikan motivasi dan cara membaca peluang usaha yang memungkinkan untuk diambil. Mengingat pentingnya berbagi ilmu dan pengalaman dari para pengusaha kepada para santri, maka perlu diadakanya Pengabdian Kepada Masyarakat terkait motivasi dan jiwa berwirausaha untuk para santri. Kegiatan ini dilaksanakan di Pondok Pesantren Yatim Alhanif. Beberapa metode yang digunakan dalam pelatihan ini adalah, ceramah, diskusi kelompok dan berbagi pengalaman. Metode ceramah adalah metode yang digunakan, dimana pemateri dalam pelatihan memberikan penjelasan materi secara langsung kepada seluruh peserta. Metode diskusi dilakukan pada saat pemateri mengajukan kasus kepada peserta, kemudian peserta diminta untuk berdiskusi dengan kelompoknya untuk menemukan solusi terhadap permasalahan kasus yang diajukan. Hasil dari kegiatan pengabdian ini adalah para santri dapat lebih teredukasi terkait cara membangkitkan motivasi dan jiwa kewirausahaan serta cara membaca peluang usaha yang bisa diambil oleh mereka. Sehingga para santri dapat ikut berperan serta mewarnai kegiatan Usaha Kecil dan Menengah di Indonesia. Dengan demikian, diharapkan kegiatan Usaha Kecil dan Menengah di Indonesia dapat maju dan berkembang.
\end{abstract}

Kata Kunci : Motivasi, Jiwa Kewirausahaan, Pondok Pesantren

\title{
A. PENDAHULUAN
}

Kemajuan ekonomi suatu bangsa tidak hanya ditentukan oleh sumber daya alam yang dimiliki oleh bangsa tersebut akan tetapi kemampuan sumber daya manusia memiliki peran yang sangat penting untuk mampu menggerakkan semua potensi yang ada untuk meningkatkan kemampuan ekonomi bangsa itu sendiri. Kenyataan menunjukan bahwa, negara dengan tingkat pertumbuhan ekonomi yang tinggi saat ini tidak tergantung pada potensi sumber daya alam yang dimilikinya. Beberapa negara yang bisa kita lihat saat ini adalah Jepang, Singapura dan Taiwan yang saat ini telah menjadi negara industri dengan tingkat pertumbuhan eknomi yang sangat diperhitungkan dalam percaturan ekonomi global. 
Pertumbuhan ekonomi sebuah negara tidak hanya tergantung kepada pemerintah untuk mengelola dan menggerakkan semua potensi sumber daya alamnya akan tetapi bagaimana pemerintah mampu menggerakkan sektor-sektor swasta dan memberikan regulasi dan fasilitas kepada masyarakat untuk mendapatkan akses serta memberikan kesempatan kepada semua pihak untuk bisa berinvestasi dalam menggerakan roda perekonomian masyarakat. Kenyataan menunjukan bahwa ketika badai krisis ekonomi yang melanda beberapa negara di kawasan Asia termasuk Indonesia, banyak sektor keuangan yang dikendalikan oleh pemerintah mengalami krisis yang parah, akan tetapi sektor-sektor rill seperti UKM (Usaha Kecil Menengah) lebih bertahan dalam menghadapi krisis saat itu. Untuk menjawab tantangan dan kebutuhan akan pertumbuhan ekonomi Indonesia agar bisa bersaing dengan negara lain, maka pemerintah perlu memberikan kemudahan-kemudahan fasilitas dan regulasi serta pendidikan dan ketrampilan dan mendorong masyarakat untuk berjiwa wirausaha (enterpreneurship) sehingga masyarakat dapat menciptakan lapangan kerja baru. Oleh karena itu, jiwa kewirausahaan harus dibangun dari sekolah melalui pendidikan formal maupun non formal.

Kewirausahaan juga memiliki peranan penting untuk menjadikan masyarakat lebih kreatif dan mandiri. Dengan adanya kewirausahaan masyarakat dapat mempunyai kemampuan untuk menciptakan dan menyediakan produk yang bernilai tambah atau inovasiinovasi yang baru sehingga dapat menjadikan masyarakat lebih kreatif dalam menyampaikan ide-ide dan kreasinya, mereka bisa menciptakan barang yang dirasa perlu dan penting untuk kesejahteraan masyarakat itu sendiri sehingga tidak perlu mengimpor dari luar negeri. Selain itu masyarakat tidak tergantung dengan pemerintah seperti tenaga kerja negri (PNS) yang masih di gaji oleh pemerintah, bahkan seorang wirausaha akan mendatangkan omset yang akan di berikan ke negara melalui pajak. Secara tidak langsung kesejahteraan ekonomi masyarakat bisa stabil. Alasan ketiga mengapa wirausaha berpengaruh terhadap pertumbuhan ekonomi di Indonesia adalah menarik invesrtor asing untuk berinverstasi atau menanamkan modalnya di Indonesia.

Untuk menjadi wirausaha perlu mempunyai modal dasar yang kuat, konsep dan strategi dalam menghadapi situasi sulit untuk dapat bersaing dalam menghadapi tantangan terutama dalam perekonomian saat ini maupun yang akan datang. Wirausaha saat ini tidak bisa lagi menghindar dari situasi dan kondisi perdagangan bebas dunia, apalagi kalau ingin berperan lebih besar di perekonomian dunia. Wirausaha perlu akses pasar sebesar-besarnya ke pasar dunia, dan sebaliknya juga dituntut oleh pelaku usaha global untuk membuka pasar domestik, karena eksistensi dan peran wirausaha pada tahun 2007 mencapai mencapai 49,84 juta unit usaha dan merupakan 99,99\% dari pelaku usaha nasional, dalam tata perekonomian nasional sudah tidak diragukan lagi dengan melihat kontribusinya dalam penyerapan tenaga kerja, pembentukan Produk Domestik Bruto (PDB) Nasional, nilai ekspor nasional, dan investasi nasional. Saat ini jumlah wirausaha di Indonesia hanya 570.339 orang atau $0,24 \%$ dari jumlah penduduk yang sebanyak 237,64 juta orang. Padahal untuk jadi bangsa maju, dibutuhkan wirausaha minimal $2 \%$ dari jumlah penduduk. program wirausaha produktif menjadi salah satu prioritas kerja utama. Hal ini dikarenakan wirausaha mempunyai nilai strategis dalam 
meningkatkan kesejahteraan masyarakat, mengurangi angka pengangguran, memperluas lapangan dan kesempatan kerja baru serta menopang perekonomian negara.

Pondok Pesantren Yatim Al-Hanif yang didirikan oleh Ustadz Akhmad Jazuli merupakan salah satu pesantren yang ada di Kelurahan Serua Kecamatan Ciputat Kota Tangerang Selatan. Pondok pesantren Al-Hanif memiliki kurang lebih 250 santri yang sebagian besar merupakan anak-anak yatim maupun dhuafa yang datang dari berbagai daerah untuk menuntut ilmu diantaranya Bogor, Palembang bahkan dari Medan. Pesantren Al-Hanif ini sendiri mengajarkan kepada para santrinya untuk berkreativitas baik dalam bidang seni maupun olahraga, diantaranya dalam bidang seni dengan adanya latihan marawis, terbukti marawis dari Pondok Pesantren Al-Hanif ini sering mengisi acara di acara hajatan-hajatan baik nikahan ataupun acara yang lainnya. Pengembangan bahasa arab dan bahasa inggris, pengajian kitab kuning, hadist, safinah tunaj ah, lim muta'lim, mahfujot, tijan darori, tanki'ul, tilawah dan tahfizh Al-Quran. Pondok pesantren Al-Hanif memiliki banyak angan-angan untuk mendirikan sebuah usaha, namun hanya sebatas angan karena keterbatasan modal untuk memulai sebuah usaha. Usaha yang sudah mulai berjalan antara lain kafe serta agrikultur alpukat yang masih merintis. Adapun hasil identifikasi masalah yang dilakukan terhadap santri di Yayasan Pondok Pesantren Yatim Al-Hanif antara lain : Santri Yayasan Pondok Pesantren Yatim Al-Hanif sebagian besar memiliki latar belakang ekonomi kurang mampu, dan memiliki kemampuan atau skill yang minim, hal ini membuat mereka memiliki posisi tawar yang rendah dalam dunia kerja. Kedua, belum adanya unit usaha yang dapat diandalkan untuk memenuhi kebutuhan pondok pesantren, sebelumnya pondok pesantren AlHanif sudah merintis kafe namun ditengah kondisi pandemi seperti ini membuat kafe sepi pengunjung. Ketiga, motivasi mereka dalam bekerja masih terbatas untuk mencukupi kebutuhan hidup, bukan secara jangka panjang untuk menambah bekal di masa depan. Keempat, pengetahuan dan ketrampilan wirausaha santri yang masih minim. Mereka masih kurang ilmu dalam menjalankan usaha. Selain itu juga mereka terkendala oleh modal yang minim. Sehingga akhirnya usaha mereka harus terhenti karena tidak mampu mengatasi masalah yang dihadapi dalam usaha.

Saat ini pesantren berfungsi tidak hanya sebagai pusat pendidikan agama bagi para santri, tetapi juga merupakan roda penggerak ekonomi bagi masyarakat sekitar. Sehingga pondok pesantren tidak hanya berfungsi sebagai pendidik sekaligus pembina kehidupan bermasyarakat. Oleh karena itu pondok pesantren memerlukan pengembangan wirausaha bagi santri. Dengan mempertimbangkan permasalahan dan kondisi Pondok Pesantren Yatim Al-Hanif, maka kami dari tim dosen manajemen Universitas Pamulang melaksanakan kegiatan pengabdian kepada masyarakat dengan tujuan memberikan pelatihan kewirausahaan untuk memotivasi dan meningkatkan minat para santri terhadap kewirausahaan.

\section{B. METODE PELAKSANAAN KEGIATAN}

Berdasarkan permasalahan yang dihadapi mitra, maka akan dilakukan pelatihan softskill kepada para santri di Pondok Pesantren Al-Hanif. Metode yang digunakan dalam pelatihan softskill ini adalah metode pembelajaran partisipatif. Dimana peserta diajak berperan serta secara aktif dalam pelatihan, tidak sekedar sebagai pendengar, tetapi juga aktif 
memberikan masukan, pertanyaan, atau bahkan menambahkan materi yang sudah disampaikan oleh pemateri.

Beberapa metode yang digunakan dalam pelatihan ini adalah, ceramah, diskusi kelompok, sharing pengalaman. Metode ceramah, adalah metode yang digunakan, dimana pemateri dalam pelatihan memberikan penjelasan materi secara langsung kepada seluruh peserta. Metode diskusi dilakukan pada saat pemateri mengajukan kasus kepada peserta, kemudian peserta diminta untuk berdiskusi dengan kelompoknya untuk menemukan solusi terhadap permasalahan kasus yang diajukan. Metode diskusi ini juga digunakan saat peserta ada yang bertanya, pemateri tidak langsung menjawab, tetapi dilempar terlebih dahulu ke forum, dan didiskusikan di antara peserta. Metode sharing pengalaman dalam pelatihan ini diwujudkan dalam bentuk sharing pengalaman oleh pelaku bisnis yang sudah berhasil.

\section{HASIL DAN PEMBAHASAN}

\section{Tahap Persiapan}

a. Observasi

Tim dosen melakukan observasi berupa survey awal pada hari Minggu 8 November 2020 di Pondok Pesantren Yatim Al-Hanif khususnya dalam hal kegiatan kewirausahaan, mengidentifikasi permasalahn yang di hadapi oleh mitra atau pondok pesantren, sekaligus memberikan pemahaman kegiatan yang akan dilaksanakan dengan pihak pengurus pondok pesantren hingga mencapai kesepakatan untuk dilaksanakannya kegiatan.

b. Koordinasi dengan pihak pesantren

Setelah melakukan survey dilakukan koordinasi dengan pihak pesantren untuk menentukan waktu yang tepat dilakukan rapat korodinasi dengan tetap memperhatikan himbauan social distancing.

c. Melakukan rapat koordinasi

Setelah melakukan koordinasi dengan pihak pesantren selanjutnya pada hari Senin 9 November 2020 menentukan lokasi pelaksaaan, serta mempersiapkan sarana dan prasarana yang menunjuang kegiatan pengabdian.

d. Membuat rencana kegiatan program

Setelah diperoleh data terkait lokasi dan kesiapan sarana dan prasarana yang dibutuhkan, selanjutnya membuat rencana kegiatan terkait target peserta, jadwal pelaksanaan dengan tetap mempertimbangkan himbauan social distancing.

\section{Tahap Pelaksanaan}

Kegiatan Pengabdian Kepada Masyarakat berupan pelatihan kewirausahaan dilaksanakan pada hari Selasa 10 November 2020. Adapun bentuk kegiatan berupa:

a. Pra-Kegiatan

Mengkondisikan lokasi kegiatan dan santri yang akan melakukan pelatihan softskill kewirausahaan dengan memperhatikan himbauan social distancing.

b. Pembukaan 
Sambutan Ketua Pengabdian Kepada Masyarakat, Sambutan Pimpinan Pondok Pesantren. Setelah dilakukan pembukaan dilanjutkan dengan acara pelatihan softskill dengan tetap memperhatikan himbauan social distancing.

c. Kegiatan atau acara inti

Pelatihan softskill kewirausahaan yang sudah disepakati, diselenggarakan di aula pondok pesantren merupakan pelatihan tekait dengan motivasi berwirausaha, teori dasar berwirusaha berdasarkan metode partisipatif. Dimana peserta diajak berperan secara aktif dalam pelatihan tidak hanya menjadi pendengar, tetap juga aktif memberikan masukan, pertanyaam atau bahkan menambahkan materi yang sudah disampaikan oleh pemateri.

d. Evaluasi pelatihan

Evaluasi pelatihan dilaksanakan sebelum acara pelatihan ditutup. Dalam acara pelatihan para santri diminta untuk mengevaluasi pelatihan yang sudah mereka lakukan, dan mendiskusikan rencana tindak lanjut yang akan dilakukan oleh para santri seperti mencoba usaha baru, dan mengembangkan usaha yang sudah ada sebelumnya.

e. Penutup dan Doa

Kegiatan penutup dan doa menandakan berakhirnya acara pelatihan.

\section{Tahap Akhir}

a. Laporan kegiatan

Tim dosen Pengabdian Kepada Masyarakat membuat laporan kegiatan dari kegiatan pelatihan yang sudah dilakukan di Pondok Pesantren Yatim Al-Hanif.

b. Luaran

Tim dosen Pengabdian Kepada Masyarakat membuat luaran dari kegiatan Pengabdian Kepada Masyarakat yang sudah terlaksana dalam bentuk jurnal dan berita online.

\section{KESIMPULAN DAN SARAN Simpulan}

Pelaksanaan kegiatan Pengabdian Kepada Masyarakat oleh Lembaga Penelitian dan Pengabdian Masyarakat Universitas Pamulang dan Dosen-Dosen Program Studi Manajemen, bertempat di Pondok Pesantren Yatim Alhanif. Kegiatan pengabdian ini, berlangsung dari tanggal 8 November sampai dengan 10 November 2020. Kegiatan ini telah berjalan dengan lancar serta mendapat sambutan hangat dari pimpinan pondok pesantren Alhanif Bapak KH.Ahmad Jazuli, beserta para santriwan dan santriwati disana. Dan dapat disimpulkan bahwa para santri dapat lebih teredukasi terkait cara membangkitkan motivasi dan kewirausahaan serta cara membaca peluang usaha yang bisa diambil oleh mereka.

\section{Saran}

Berdasarkan kegiatan yang sudah terlaksana, beberapa saran untuk kegiatan Pengabdian Kepada Masyarakat kali ini adalah motivasi dan jiwa kewirausahaan dalam hati para santri, harus dapat ditumbuhkan dan dipertahankan gelora semangatnya. Serta tidak lupa untuk selalu berdoa dan meminta petunjuk kepada Yang Maha Kuasa, agar dapat membaca peluang dan mengambil langkah yang tepat dalam mengambil keputusan. Sehingga para santri dapat ikut berperan serta mewarnai kegiatan Usaha Kecil dan Menengah di Indonesia. 
Dengan demikian, diharapkan kegiatan Usaha Kecil dan Menengah di Indonesia dapat maju dan berkembang.

\section{DAFTAR PUSTAKA}

Dian Retnaningdyah et al. (2014) "Peningkatan dan Pengembangan Daya Saing bagi UMKM Kripik Salak di Kabupaten Sleman”. Jurnal Telaah Bisnis Vol.15, No.1, hal 30-40.

Maisaroh, Tatik. (2019).’Perintisan Kewirausahaan Berbasis Pesantren Melalui Pelatihan dan Pendampingan Kewirausahaan Pada Santri PP Ar Risalah Mlangi Yogyakarta”. Jurnal Abdimas Madani dan Lestari. Vol. 01, Issue. 01, hal 34-40.

Undang-Undang No.20 Tahun 2008 tentang Usaha Kecil, Mikro dan Menengah.

https://finance.detik.com. RI Butuh 4,18 Juta Wirausaha Baru, Cak Imin Latih Pengangguran SD dan Sarjana. (diakses 17 Desember 2020)

https://www.tribunnews.com. Teten: Jumlah Wirausahawan di Indonesia Masih Terlalu kecil. (diakses 17 Desember 2020)

https://www.wartaekonomi.co.id. Kemnakertrans Kembangkan Inkubator Wirausaha Dengan Tujuh Negara. (diakses 17 Desember 2020) 